\title{
Front Matter: Volume 11034
}

, "Front Matter: Volume 11034," Proc. SPIE 11034, Short-pulse High-energy Lasers and Ultrafast Optical Technologies, 1103401 (4 June 2019); doi:

$10.1117 / 12.2535779$

SPIE. Event: SPIE Optics + Optoelectronics, 2019, Prague, Czech Republic 


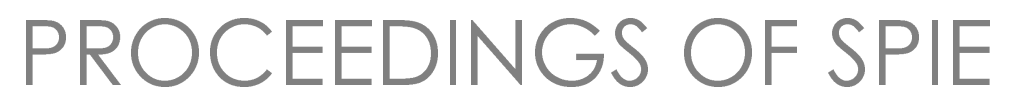

\title{
Short-pulse High-energy Lasers and Ultrafast Optical Technologies
}

\author{
Pavel Bakule \\ Constantin L. Haefner \\ Editors
}

1-3 April 2019

Prague, Czech Republic

Sponsored by

SPIE

Cooperating Organisations

ELI Beamlines (Czech Republic)

Laserlab Europe

European Optical Society

HiLASE (Czech Republic)

Published by

SPIE 
The papers in this volume were part of the technical conference cited on the cover and title page. Papers were selected and subject to review by the editors and conference program committee. Some conference presentations may not be available for publication. Additional papers and presentation recordings may be available online in the SPIE Digital Library at SPIEDigitalLibrary.org.

The papers reflect the work and thoughts of the authors and are published herein as submitted. The publisher is not responsible for the validity of the information or for any outcomes resulting from reliance thereon.

Please use the following format to cite material from these proceedings:

Author(s), "Title of Paper," in Short-pulse High-energy Lasers and Ultrafast Optical Technologies, edited by Pavel Bakule, Constantin L. Haefner, Proceedings of SPIE Vol. 11034 (SPIE, Bellingham, WA, 2019) Seven-digit Article CID Number.

ISSN: 0277-786X

ISSN: 1996-756X (electronic)

ISBN: 9781510627345

ISBN: 9781510627352 (electronic)

Published by

SPIE

P.O. Box 10, Bellingham, Washington 98227-0010 USA

Telephone +1360 676 3290 (Pacific Time) · Fax +1 3606471445

SPIE.org

Copyright @ 2019, Society of Photo-Optical Instrumentation Engineers.

Copying of material in this book for internal or personal use, or for the internal or personal use of specific clients, beyond the fair use provisions granted by the U.S. Copyright Law is authorized by SPIE subject to payment of copying fees. The Transactional Reporting Service base fee for this volume is $\$ 18.00$ per article (or portion thereof), which should be paid directly to the Copyright Clearance Center (CCC), 222 Rosewood Drive, Danvers, MA 01923. Payment may also be made electronically through CCC Online at copyright.com. Other copying for republication, resale, advertising or promotion, or any form of systematic or multiple reproduction of any material in this book is prohibited except with permission in writing from the publisher. The CCC fee code is 0277$786 \times / 19 / \$ 18.00$.

Printed in the United States of America by Curran Associates, Inc., under license from SPIE.

Publication of record for individual papers is online in the SPIE Digital Library.

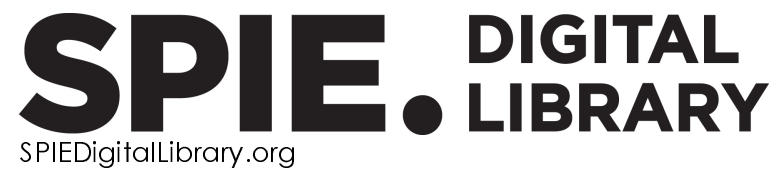

Paper Numbering: Proceedings of SPIE follow an e-First publication model. A unique citation identifier (CID) number is assigned to each article at the time of publication. Utilization of CIDs allows articles to be fully citable as soon as they are published online, and connects the same identifier to all online and print versions of the publication. SPIE uses a seven-digit CID article numbering system structured as follows:

- The first five digits correspond to the SPIE volume number.

- The last two digits indicate publication order within the volume using a Base 36 numbering system employing both numerals and letters. These two-number sets start with $00,01,02,03,04$, 05, 06, 07, 08, 09, OA, OB ... 0Z, followed by 10-1Z, 20-2Z, etc. The CID Number appears on each page of the manuscript. 


\section{Contents}

$\begin{array}{ll}\vee & \text { Authors } \\ \text { vii } & \text { Conference Committee }\end{array}$

LARGE-SCALE PW LASERS

$1103407 \quad$ Laser technology development for high peak power lasers achieving kilowatt average power and beyond (Invited Paper) [1 1034-5]

DISPERSION MANAGEMENT IN SHORT PULSE LASERS

11034 OC Spectral shaping of a $5 \mathrm{~Hz}$, multi-joule OPCPA frontend for a $10 \mathrm{PW}$ laser system [1 1034-10]

TEMPORAL CONTRAST IN HIGH-INTENSITY LASERS

11034 OD Spatiotemporal analysis of plasma mirrors for high-contrast ultra-intense laser pulses [1 1034-1 1]

11034 OF Temporal pre-pulse generation in high-intensity CPA lasers from imperfect domain orientation in anisotropic crystals [1 1034-13]

11034 OG Passive laser pulse intensity stabilization through a balance of self-phase modulation and dispersion [1 1034-14]

$11034 \mathrm{OH} \quad$ On target contrast ratio study for petawatt level femtosecond laser system [11034-15]

OPCPA-BASED SHORT PULSE LASER SYSTEMS

$11034 \mathrm{Ol} \quad$ High-repetition rate optical parametric chirped pulse amplification system for attosecond science experiments (Invited Paper) [11034-16]

11034 OM The construction of Allegra kilohertz femtosecond laser system at ELI-Beamlines [1 1034-20]

TECHNOLOGY AND MATERIALS FOR PW LASERS

11034 ON High-power ultrafast industrial thin-disk lasers (Invited Paper) [11034-21] 
11034 OP The beam dump materials and their LIDT measurements for PW/multi-PW laser systems [1 1034-24]

\section{POSTER SESSION}

$110340 Q \quad$ Peak power measurement of nanoscale short-pulse laser [11034-25]

11034 OT Single-shot surface ablation and transient reflectivity changes of optical glasses induced by 34 fs laser pulses [1 1034-29]

$11034 \mathrm{OU} \quad$ High order harmonics in modulated slab waveguide [1 1034-30] 


\section{Authors}

Numbers in the index correspond to the last two digits of the seven-digit citation identifier (CID) article numbering system used in Proceedings of SPIE. The first five digits reflect the volume number. Base 36 numbering is employed for the last two digits and indicates the order of articles within the volume. Numbers start with 00, 01, 02, 03, 04, 05, 06, 07, 08, 09, OA, OB...0Z, followed by 10-1Z, 20-2Z, etc.

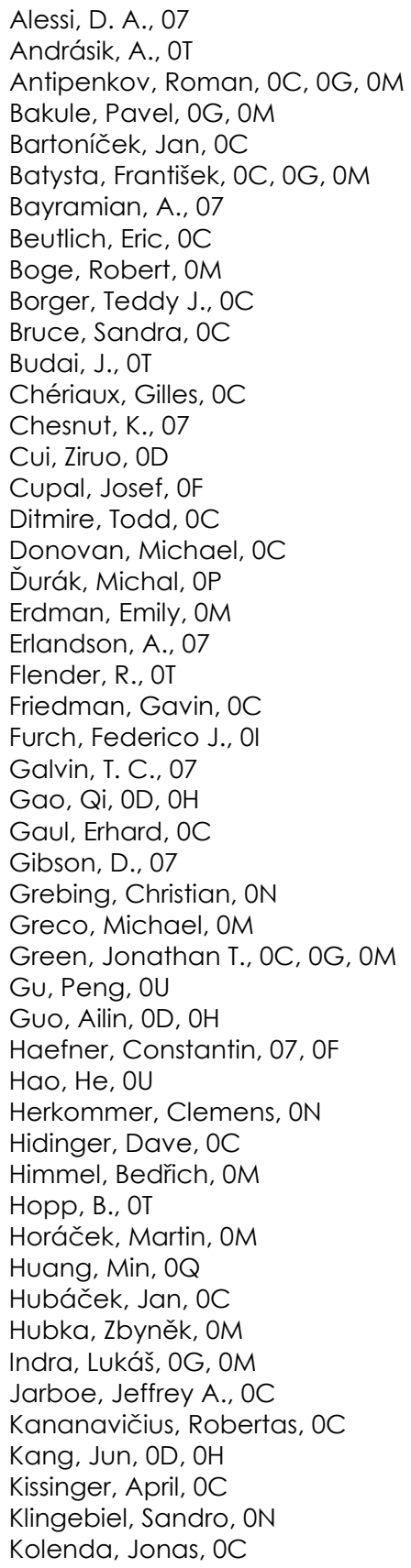

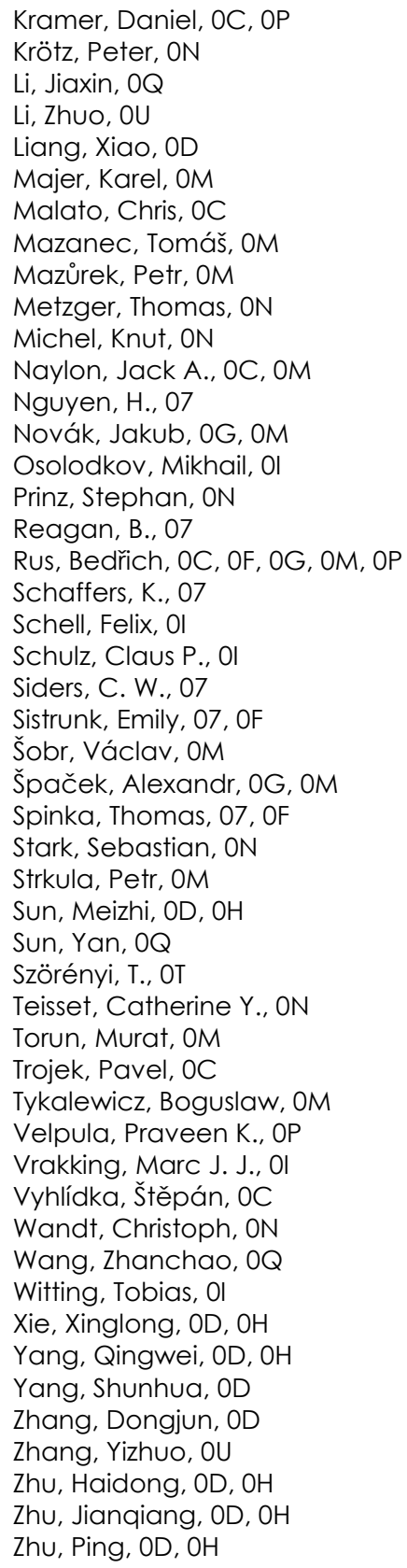


Proc. of SPIE Vol. 11034 1103401-6 Downloaded From: https://www.spiedigitallibrary.org/conference-proceedings-of-spie on 26 Apr 2023
Terms of Use: https://www.spiedigitallibrary.org/terms-of-use 


\title{
Conference Committee
}

\author{
Symposium Chairs
}

Bedrich Rus, ELI Beamlines, Institute of Physics of the CAS, v.v.i. (Czech Republic)

Chris Edwards, STFC Rutherford Appleton Laboratory

(United Kingdom)

Saša Bajt, Deutsches Elektronen-Synchrotron (Germany)

Ivo Rendina, Istituto per la Microelettronica e Microsistemi (Italy)

Mike Dunne, SLAC National Accelerator Laboratory (United States)

Honorary Symposium Chair

Erich Spitz, French Academy of Sciences, National Academy of Technologies (France) Advisor to Thales (France)

Conference Chairs

Pavel Bakule, Institute of Physics of the CAS, v.v.i. (Czech Republic)

Constantin L. Haefner, Lawrence Livermore National Laboratory (United States)

Session Chairs

1 Large-scale PW Lasers

Pavel Bakule, Institute of Physics of the CAS, v.v.i. (Czech Republic)

2 PW Pulse Beam Diagnostics

Pavel Bakule, Institute of Physics of the CAS, v.v.i. (Czech Republic)

3 Dispersion Management in Short Pulse Lasers

Pavel Bakule, Institute of Physics of the CAS, v.v.i. (Czech Republic)

4 Temporal Contrast in High-intensity Lasers

Pavel Bakule, Institute of Physics of the CAS, v.v.i. (Czech Republic)

5 OPCPA-based Short Pulse Laser Systems

Pavel Bakule, Institute of Physics of the CAS, v.v.i. (Czech Republic)

6 Technology and Materials for PW Lasers

Daniel Kramer, ELI Beamlines (Czech Republic) 
JS Joint Session: High-Peak Power Lasers

Joachim Hein, Friedrich-Schiller-Universität Jena (Germany)

Proc. of SPIE Vol. 11034 1103401-8

Downloaded From: https://www.spiedigitallibrary.org/conference-proceedings-of-spie on 26 Apr 2023 Terms of Use: https://www.spiedigitallibrary.org/terms-of-use 